\title{
Androgen-dependent proteins in the urine of bank voles (Clethrionomys glareolus)
}

\author{
M. Kruczek and A. Marchlewska-Koj \\ Department of Genetics and Evolution, Institute of Zoology, Jagiellonian University, Kraków, Poland
}

\begin{abstract}
Summary. The concentration of proteins in the urine of adult bank vole males was higher than that in urine of immature males and females. After separation of the urine by polyacrylamide gel electrophoresis in the presence of SDS, the principal urinary protein had a slightly lower mobility than cytochrome $C$. Urine from females or castrated males contained only trace amounts of this protein. Injection of testosterone into castrated males increased this protein band. We suggest that bank vole males, like those of rats and mice, synthesize and release in their urine an androgen-dependent protein fraction.
\end{abstract}

\section{Introduction}

The urine of male mice and rats contains high levels of proteins. The major urinary proteins of the mouse, or $\alpha_{2 u}$ globulin of rat urine, are an antigenically related group of acidic proteins of low molecular weight $\left(M_{\mathrm{r}} 20000\right)$ synthesized in the liver of mature males and secreted into urine (for references see: Finlayson, Asofsky, Potter \& Runner, 1965; Irvin, Lane \& Neuhaus, 1971; Roy, Chatterjee, Demyan, Nath \& Motwanik, 1982; Shaw, Held \& Hastie, 1983). It was initially thought that hormonal regulation of these urinary proteins was selectively due to androgens, since administration of testosterone to females, or to castrated male mice and rats, resulted in increase of urinary protein level. However, glucocorticoids, thyroxine and growth hormone have also been shown to be involved (Roy et al., 1982; Shaw et al., 1983).

Androgen-dependent urinary proteins have mainly been studied in the rat (Rattus norvegicus) and mouse (Mus musculus). Indirect evidence suggests that these proteins are also present in the urine of microtine rodents: the urinary protein concentration was higher in male field voles (Microtus agrestis: $3 \cdot 10 \mathrm{mg} / \mathrm{ml}$ ) and European pine voles (Pitymys subterraneus: $3.14 \mathrm{mg} / \mathrm{ml}$ ) than in the females of these species $(0.27$ and $0.53 \mathrm{mg} / \mathrm{ml}$, respectively) (A. Marchlewska-Koj, unpublished data). In the present study we have examined the androgen-dependent urinary proteins released by bank vole (Clethrionomys glareolus) males.

\section{Materials and Methods}

All experimental bank voles came from an outbred stock colony reared in our laboratory. Animals were maintained in metal cages in a photoperiod of $14 \mathrm{~h}$ light:10 h dark (lights on 06:00 h) and fed with natural foods (oats, wheat, apples and red beets) ad libitum. Wood shavings were provided as bedding and nesting material.

The urine was collected from animals reared in sexually mixed groups until weaning at 21 days of age. After weaning males and females were separated and housed 1 or 2 animals per cage during the experimental procedure. At 8 weeks of age males were castrated under pentobarbitone sodium (Vetbutal: Polfa, Pulawy, Poland) anaesthesia and 4 weeks later urine was collected. Castrated and unoperated males were injected s.c. with $500 \mu \mathrm{g}$ testosterone propionate (Polfa, Jelenia Góra, 
Poland) every day for 8 days. On Day 9 urine was collected. For urine collection animals were kept for $24 \mathrm{~h}$ in metabolism cages; the same diet was provided. The urine was then centrifuged for $5 \mathrm{~min}$ at $3000 \mathrm{~g}$ and stored at $-20^{\circ} \mathrm{C}$ until used.

After thawing the protein fraction of the urine was salted out with solid ammonium sulphate at $80 \%$ saturation. The precipitate was centrifuged, dissolved in distilled water to the original volume and dialysed overnight at $+4^{\circ} \mathrm{C}$ in Visking Tubing $8 / 31$ (The Scientific Instrument Centre, London, U.K.) against $0.075 \mathrm{M}-\mathrm{NaCl}-0.05 \mathrm{M}$-phosphate, $\mathrm{pH} 7 \cdot 4$. The concentration of protein was estimated by the method of Lowry, Rosebrough, Farr \& Randall (1951).

Chromatography. A $20 \mathrm{ml}$ portion of pooled urine was centrifuged and evaporated to $2 \mathrm{ml}$ volume at $+38^{\circ} \mathrm{C}$ using a rotatory vacuum evaporator. A sample was applied to a Sephadex G-75 column $(25 \times 410 \mathrm{~mm})$ and eluted with $0.075 \mathrm{M}-\mathrm{NaCl}-0.05 \mathrm{M}$-phosphate, $\mathrm{pH} 7.4$. Fractions of $2.0 \mathrm{ml}$ were collected and the optical density was measured at $280 \mathrm{~nm}$. Blue dextran (Pharmacia, Uppsala, Sweden), cytochrome C and L-alanine (Serva, Heidelberg, West Germany) were used as standards.

Electrophoretic separation of urinary proteins. Pooled urine $(\sim 10 \mathrm{ml})$ was dialysed overnight at $+4^{\circ} \mathrm{C}$ against $0.005 \mathrm{M}$-Tris-glycine buffer $\mathrm{pH} 8.3$, centrifuged for $5 \mathrm{~min}$ at $10000 \mathrm{~g}$ and concentrated 5-fold by ultrafiltration on an Amicon YM-10 membrane.

Samples of concentrated urine were separated by polyacrylamide gel electrophoresis in Tris-glycine buffer $\mathrm{pH} 8.3$ (Gordon, 1969) or by polyacrylamide gel electrophoresis with $0 \cdot 1 \%$ sodium dodecyl sulphate at pH 7.0 (Weber \& Osborn, 1969). For the latter, bovine serum albumin, chicken ovalbumin and horse cytochrome $\mathrm{C}$ were used as protein standards.

The data were analysed with a one-way analysis of variance and post-hoc comparisons were made with Duncan's new multiple range test.

\section{Results}

The concentration of proteins in adult male urine was higher than that in the urine of immature male or female bank voles (Table 1). Castration decreased the proportion of protein in the urine but this effect could be completely reversed by injection of testosterone.

After separation of the adult male urine on a Sephadex G-75 column two peaks were found (Text-fig. 1). The first peak corresponded to the protein fraction and the broad second-peak to lower molecular weight substances representing urinary chromophores. The comparison of elution patterns of urine from unoperated, castrated and castrated + testosterone-treated males revealed quantitative differences (Text-fig. 1).

Table 1. Amounts of proteins in the urine of male and female bank voles

\begin{tabular}{lcccc}
\hline & $\begin{array}{c}\text { No. of } \\
\text { animals }\end{array}$ & $\begin{array}{c}\text { Protein level } \\
(\mathrm{mg} / \mathrm{ml})\end{array}$ & $\begin{array}{c}\text { ANOVA } \\
\text { Duncan's test }\end{array}$ \\
\hline Females & 12 & $0.28 \pm 0.02^{\mathrm{a}}$ & $\mathrm{F}_{(7,79)}$ & $P<0.01$ \\
Males & 10 & $0.31 \pm 0.02^{\mathrm{b}}$ & $\mathrm{a}-\mathrm{d} v s \mathrm{e}$ & $P<0.01$ \\
$\quad 3$ weeks old & 12 & $0.38 \pm 0.05^{\mathrm{c}}$ & & \\
4 weeks old & 10 & $0.35 \pm 0.03^{\mathrm{d}}$ & & \\
6 weeks old & 12 & $0.83 \pm 0.04^{\mathrm{e}}$ & $\mathrm{e} v s \mathrm{f}, \mathrm{g}, \mathrm{h}$ & $P<0.01$ \\
12 weeks old & 10 & $0.32 \pm 0.03^{\mathrm{f}}$ & $\mathrm{f} v s \mathrm{~g}, \mathrm{~h}$ & $P<0.01$ \\
Intact & 10 & $1.06 \pm 0.04^{\mathrm{g}}$ & $\mathrm{g} v s \mathrm{~h}$ & $P<0.01$ \\
Castrated & 11 & $1.39 \pm 0.12^{\mathrm{h}}$ & & \\
$\quad$ Castrated + testosterone & & & & \\
Intact + testosterone & & & & \\
\hline
\end{tabular}

Values are mean \pm 's.e.m. 


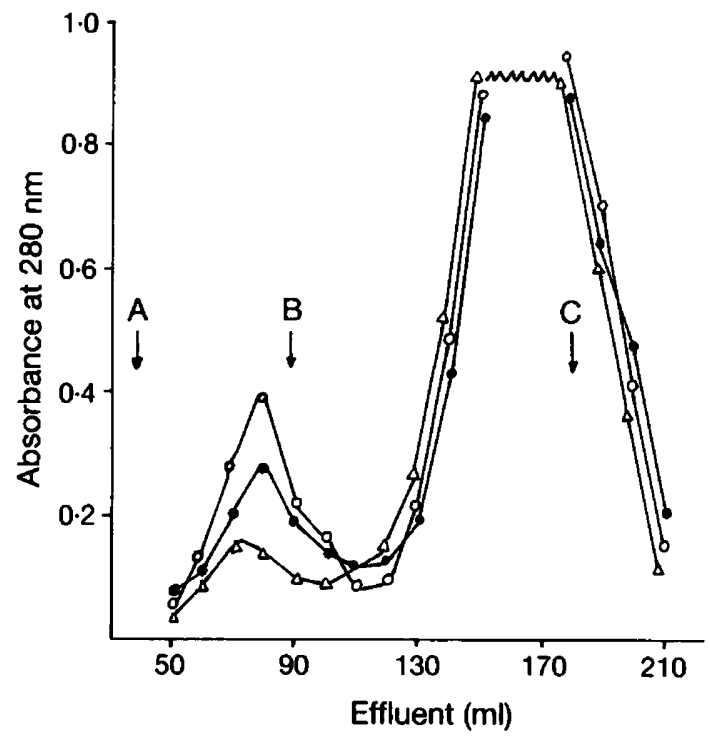

Text-fig. 1. Filtration of 10 -fold concentrated urine of male bank voles on a Sephadex G-75 column. Arrows indicate elution volumes of the following molecular weight markers: A, blue dextran; B, cytochrome C; C, L-alanine.

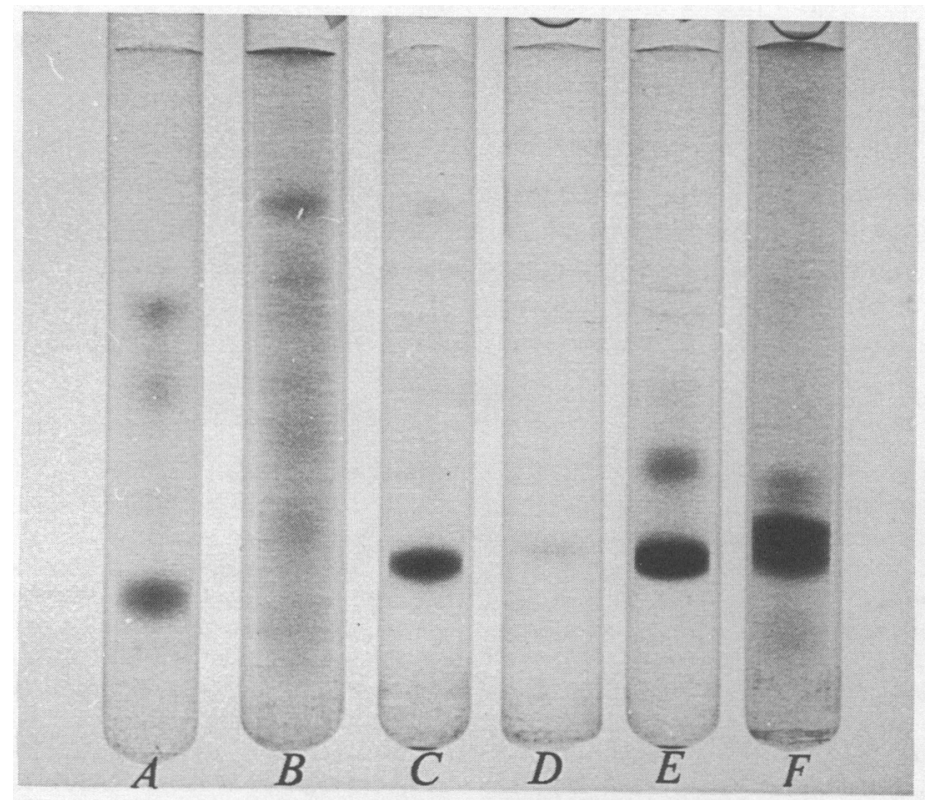

Text-fig. 2. Separation of urinary proteins by polyacrylamide gel electrophoresis in the presence of SDS (anode at the bottom). A, protein standards $(5 \mu \mathrm{g})$ listed in order from the top: bovine serum albumin $\left(M_{\mathrm{r}} 68000\right)$, chicken ovalbumin $\left(M_{\mathrm{r}} 43000\right)$, horse cytochrome C $\left(M_{\mathrm{r}}\right.$ 13400 ); B, $60 \mu$ l concentrated urine from bank vole females; $\mathrm{C}, 15 \mu$ l concentrated urine from intact bank vole males; D, $15 \mu \mathrm{l}$ concentrated urine from castrated bank vole males; $\mathrm{E}, 15 \mu \mathrm{l}$ concentrated urine from bank vole males castrated and treated with testosterone; $F, 15 \mu l$ concentrated urine from outbred mouse males. 
Additional information was obtained by polyacrylamide gel electrophoresis of dialysed and concentrated urine. As shown in Text-fig. 2 the urine from adult intact males contained a protein which in the presence of SDS had a slightly lower mobility than cytochrome $\mathrm{C}(\mathrm{Gel} \mathrm{C})$. Urine from females or castrated males contained only trace amounts of this protein (Gels B and D). Injection of testosterone into castrated males considerably increased this protein band and some other compounds of lower mobility also became visible ( $\mathrm{Gel} \mathrm{E}$ ). The picture in Gel $\mathrm{E}$ is similar to that in $\mathrm{Gel} F$ for adult mouse male urine, although in the latter the main protein component occurred as a double band. When subjected to ordinary polyacrylamide gel electrophoresis in the absence of SDS the major urinary proteins of bank voles and mice migrated similarly to plasma albumin (results not shown).

\section{Discussion}

The present experiments indicate that proteins occur in the urine of mature bank vole males. Their content is reduced by castration but can be increased even above the normal level by subsequent treatment with testosterone. The biological function of such urinary proteins is unknown but they may be involved in the transport and secretion of pheromones. Mouse male olfactory stimulants that accelerate puberty (Vandenbergh, Whitsett \& Lombardi, 1975) or stimulate the oestrous cycle and block of pregnancy (Marchlewska-Koj, 1977) in females are androgen-dependent substances excreted with urine in a protein-bound form. This supposition is also indirectly supported by the observations of Shaw et al. (1983) who demonstrated the occurrence of m-RNA for urinary proteins not only in the male liver but also in the lachrymal and submaxillary glands of mice. Like urine, saliva represents external secretory products which may be used as a source of stimulants for chemical communication of mammals. In boars, the submaxillary salivary glands contain large amounts of proteins with a high affinity for pheromone that facilitates the adoption of the mating stance in oestrous pigs (Booth, 1984). This protein is thought to be important for the storage and secretion of the biologically active substance into the saliva in male pigs.

We thank Dr Aleksander Koj of the Molecular Biology Institute, Jagiellonian University, for help in designing the experiments and critical review of the manuscript. This research was supported by Grant MR-II/10 from the Polish Academy of Sciences.

\section{References}

Booth, W.D. (1984) Sexual dimorphism involving steroidal pheromones and their binding protein in the submaxillary salivary gland of the Göttingen miniature pig. J. Endocr. 100, 195-202.

Finlayson, J.S., Asofsky, R., Potter, M. \& Runner, C.C. (I965) Major urinary protein complex of normal mice: origin. Science, N.Y. 149, 981-982.

Gordon, A.H. (1969) Electrophoresis of proteins in polyacrylamide and starch gels. In Laboratory Techniques in Biochemistry and Molecular Biology, pp. I-49. Eds T. S. Work \& E. Work. North Holland, Amsterdam.

Irvin, J.F., Lane, S.E. \& Neuhaus, O.W. (1971) Synergistic effect of glucocorticoids and androgens on the biosynthesis of sex-dependent protein in male rat. Biochim. Biophys. Acta 252, 328-334.

Lowry, L.O.H., Rosebrough, N.J., Farr, A.L. \& Randall, R.J. (1951) Protein measurement with the Folin phenol reagent. J. biol. Chem. 193, 265-272.
Marchlewska-Koj, A. (1977) Pregnancy block elicited by urinary proteins of male mice. Biol. Reprod. 17, $729-732$.

Roy, A., Chatterjee, B., Demyan, W., Nath, T. \& Motwanik, N. (1982) Pretranslational regulation of $\alpha_{2 \mathrm{u}}$-globulin in rat liver by growth hormone. J. biol. Chem. 257, $7834-7838$.

Shaw, P.H., Held, W.A. \& Hastie, N.D. (1983) The gene family from urinary proteins: expression in several tissues of the mouse. Cell 32, 755-761.

Vandenbergh, J., Whitsett, J.M. \& Lombardi, J.R. (1975) Partial isolation of a pheromone accelerating puberty in female mice. J. Reprod. Fert. 43, 515-523.

Weber, K. \& Osborn, M. (1969) The reliability of molecular weight determination by sodium dodecyl sulfate-polyacrylamide gel electrophoresis. J. biol. Chem. 244, 4406-4412. 